\title{
Perceived restoration scale method turned into (used as the) evaluation tool for parks and open green spaces, using Tartu city parks as an example
}

Piret Rennit and Kadri Maikov*

\begin{abstract}
Estonian parks are well known for their history and dendrology. Usually, city maps show no nuances of the green areas, they could be for example abandoned areas, parks, green squares, usable/non-usable areas for the community. In this study ALL 92 parks and urban open green spaces (UGS) of the Estonian city Tartu are explored using a PRS method tool for evaluating open green spaces. Due to the densification of cities, which is also a current issue in Estonia, it is important to provide a variety of knowledge of UGS to support the everyday life of city dwellers. We know a lot about the connections between nature and human well-being, but how do we really evaluate the greenery? Tartu's parks and UGS were analysed by an expert in the summer of 2013, by using the Perceived Restorative Scale (PRS) through tools like Being away, Fascination, Coherence, Compatibility. PRS method is used to evaluate the green areas along these lines: 0-do not exist, 1-low existence, 2 - medium existence, 3-high existence. The study includes 92 UGS, of which 24 are located in the city center, 11 in Tähtvere borough, 8 in Ihaste and Annelinn, 3 in Jaamamõisa, 2 in Ropka and Ropka industry division and 1 in Veeriku, Vaksali area and in Supilinn. There were no UGS in Ränilinn. Description of green spaces is based on detailed level of item question correlation results and CAD MAPS are created by average results of one subscale question (described in detail on method part). The main results are as follows: Item of Fascination 'This place has fascinating qualities' and item of Being away 'Being here is like an escape experience' correlate $(r=0.760, p<0.05)$ in areas $B S, A M, A K, C O, C L, C P$, $C N, O, B J, A R, A E, B O \tilde{O}$ (See Figure 1. Item of Fascination 'My attention is drawn to many interesting things' correlate with items of Being away 'Being here is like an escape' $(r=0.689, p<0.05)$ and 'This place makes it possible for me to rest from daily routine' $(r=0.771, p<0.05)$. Both correlations were highly esteemed in areas $B S, A U ̈, A K, C L, C P$, CO, O, CN, AR, BÕ (See Figure 1/Group III.) The outcome: A CAD-file showing where the different qualities are located in the city. Based on the results the authors can confirm that such UGSs as the Toome Hill and Kassitoome Park can be considered the model parks of the city of Tartu.
\end{abstract}

Keywords: CAD MAP; Example parks; Descriptions

* Correspondence: kadri.maikov@emu.ee

Department of Landscape Architecture, Institute of Agricultural and

Environmental Sciences, Kreutzwaldi street 58A/3, 51014, Estonia 


\section{Background}

\section{Introduction to topic}

Why do we need city parks- the research shows that high-rise housing is associated with behavioural problems (Gillis 1974). Nature offers its users the possibilities for mental development by acquiring knowledge about themselves, about nature and surroundings, their contained elements and people (Gibson 1979; Stigsdotter \& Grahn 2002; Stigsdotter and Grahn 2011, Wilson 1993). The general functions that city parks offer: contact with nature, in the broad sense of the word; possibility for physical recreation - not organised; experiencing art - garden art, pieces of art; possibility of human contact; also space for innovations and the contribution to the "mental map". It is necessary that people could trust their reactions, reflexes and emotional reactions to outdoor surroundings. In the unnatural environment of the city people cannot trust their own reactions, emotions etc. Green spaces in proximity to their home or workplace reduce the sense of mental condition imposed by urban life and significantly improve satisfaction and well-being (Kaplan 2001). Coley et al. (1997) found that the presence of trees and vegetation in outdoor public spaces was associated with the greater use of these spaces by both youth and adult population. Research shows that a small intimate park close to one's home is often highly valued and the nearer the park is to one's home the more extensive is its use (Nordh et al. 2009). They also claimed that the restorative value of a small park with one listed component, e.g. water, was almost as big as that of a medium size one component park. Similarly, a mediumsized park (with four ART components) had the same restorative value as a big park with the same number of components. Restorative environment helps to restore diminished emotional and functional resources and abilities, decrease stress. It limits negative thoughts and provokes positive emotions, as well as increases the activity of parasympathetic nervous system (regulates the recovery during recreation). Kaplan and Kaplan (1989) say that nature is especially rich in restorative potential and also that preferred environment is more likely to be a restorative environment ( $p$ 189). In the environment where all four components (ART, PRS) are represented intensively people can have a three-stage progressive recovery:

- Clearing the head -having random ideas in mind and then letting them go;

- Directed attention and focus recovery level;

- Let go to psychology gathered material of less internal noise and higher feeling calmness, what helps soft fascination. Needs from environment all components, then long time distance involvement and it stay in priorities, actions, goal etc. reflections (Han 2003; Rosenblad 2002).

PRS does not focus on one environment only, but handles several restorative environments, stressing certain qualities or the quality between the Man and the environment (Kaplan \& Kaplan 1989).

\section{Introduction to PRS}

PRS was first applied in 1996. One of the main aims of this scale is to give the designers a measurement tool that could be used to assess the impact of existing and prospective settings on people (Ivarsson \& Hagerhall 2008). It is based on Attention Restoration Theory, ART. The main ideas of ART rest on the works of William James in 1892 that contain his psychological conception on directed attention, which by nature is not interesting as it requires a lot of energy and effort. In order to restore from mental fatigue ART suggests taking up activities that require involuntary attention. Kaplan (1995) suggests perception, which gives one the sensation of feeling far away from the every-day-life, makes it possible to do something at one's free will, encourages thinking and exploration and is in harmony with one's personal needs. The scale is based on four ART characteristics, which have several variations that have developed over the years since their implementation (Kaplan 1995; Korpela \& Hartig 1996; Hartig et al. 1997a, b; Bodin \& Hartig 2003). PRS has been used in a lot of research, e.g. Hartig et al. 1996; Hartig et al. 2001; Korpela et al. 2001; Laumann et al. 2001; Berto 2005; Tenngart \& Hagerhall 2008; Nordh et al. 2009. According to the Italian version the scale consists of 26 items, which measure the perception on the basis of five restorative characters, which are Being away, Fascination, Scope, Coherence and Compatibility. In his ART theory Kaplan (1995) regards scope and coherence as one and the same characteristic he calls extent. Italian version states that restoration is carried out in a place where everything is in the right dimension (Coherence), without any limits on time and/or space (Scope), far from everyday life (Being away) and with relaxed (Fascination) and pleasant (Coherence) activity. Each characteristics is assessed on a 11-point scale, where 0 means 'not at all', 6 means 'rather a lot' and 10 'totally' (Pasini et al. 2009). It must be taken into account that PRS has been changed several times, which means that pursuant to different date we may talk about 16; 58; 29 (Hartig et al. 1996); 24 (Bodin \& Hartig 2003) or even 44 characteristics (Tian 2012). The scale created by Hartig et al. (1997a, b) with its 26 items to describe the human-environment relations with its four subscales is the best-clarified and most easily accessible scale. The four 
subscales are: Fascination, Being away, Extent, and Compatibility. Each subscale is assessed on a 7-grade scale, whereas $1=$ not at all; $2=$ very little; 3 = rather little; $4=$ so-so (not little, not much) $5=$ quite a lot; $6=$ very much; 7 = absolutely adore it (Haurua et al. 2012). In order to give a better overview of these four characteristics, they have been handled separately. (In current work the same method is used as evaluation items of greeneries, where specialists are evaluating the greenery in 4 point scale).

In current work, specialists are adopting same evaluating method of greeneries, using a 4-grade scale.

\section{Fascination}

This feature plays an important part in ART, offering the depleted power of observation some rest. Fascination can stem from different sources: process (e.g. narrative, solving different problems) or content (e.g. people, water, fire, animals, nature itself). These above-mentioned stimuli flatter people and do away with boredom; they make it possible for the Man to perform without the need to apply directed attention. (Berto et al. 2008) Fascination may, in addition to functionality, also have the dimension of attractiveness and intensity. Directed attention is used when the place lacks Fascination and other restorative features (Pasini et al. 2009). Fascination is related to the specific features of the surrounding landscape (e.g. landscape that is different from the surroundings, such as drumlins, mountains, as well as parkways lined by trees that create a private room in a specific environment). Other examples of Fascination include big meadows or open areas in a park where people like to be on sunny days, the movement of clouds in the sky, the rustle of leaves in the wind or the sound of a rivulet foaming across the stones.

\section{Being away}

Referring to this feature Kaplan and Kaplan (1989) describes three possibilities: escape from the unwanted and disturbing surroundings, retreating from everyday work and its reminders, stop purposeful or systematic activities. Town dwellers may prefer to visit a big or closed urban forest to escape from the disturbing stimuli and achieve the feeling of Being away. Restorative environment must be in harmony with the preferences and inclinations of the observer. Needs and expectations of specific people may differ (by eras, by generations, etc.). Therefore the perceptible restorative characteristics in a specific environment are not constant (Kaplan 1995). In a landscape Being away can be characterised by vegetation different from everyday surroundings (e.g. tall trees), relief; visually pleasant elements including artificial details (pavilions, plant walls). Fresh air also makes people feel that they are away from their daily routines and their physical environment (e.g. office). Being away means moving to another situation; without certain restorative qualities this situation is less likely to support restoration (Hartig et al. 1997a, b). Kaplan suggests extent as the next component (Kaplan \& Kaplan 1989).

\section{Extent}

Extent refers to a setting that has sufficient content to engage the mind for a long enough period to allow directed attention to rest. Environments with Extent are not necessarily large in size, but have interesting content. Japanese gardens form a good example here, for they may be small on a physical scale, but they have enough content and structure to engage the mind (Herzog et al. 2003). Restorative environment is tightly connected with the studies on the unity of scope and space, so that a person in the environment would not get lost or disoriented. Extent is also defined through two factors: Connectedness and Scope. Scope refers to the environment that has been extended both in space and time, so that people recognise the possibility for entering and spending their time there (Hartig et al. 1997a, b). Additionally, one can find familiar elements in extended settings, e.g. trees, bushes, flowers, decorative elements in the garden, etc. Trees and bushes create a visual space that is easy to perceive. Recurring common elements (e.g. benches with the same design, dustbins, etc.) create an environment that is perceived as a whole. Kaplan in his primary Swedish version used Coherence instead of Extent (Ivarsson \& Hagerhall 2008). Coherence was added to Extent and it would refer to both physical (e.g. the size of the area) and abstract level (a feeling that the space extends over the observed frames and time) (Haurua et al. 2012). Coherence is the primary stage of connectedness (Hartig et al. 1996).

\section{Compatibility}

An environment that is a good fit between the activities an individual wants to take part in, and the kind of activities that an environment lends itself toward has high Compatibility for that person (Kaplan 1995). On the basis of Compatibility people make their choices in everyday life. Research confirms that Compatibility can be found in settings where the desired activities comply with what the environment enables or supports (Hartig et al. $1997 \mathrm{a}, \mathrm{b})$. Although restorative action can take place with only one component present (e.g. physically being away), ART claims that restorativeness would be higher in an environment that involves all four components (Bagot 2004). This is also confirmed by research. For example, high compatibility is impossible in settings lacking high scores in Fascination, Being away and Extent (Korpela \& Hartig 1996). 


\section{Research questions}

Goal: Based on above-mentioned PRS method items to describe Tartu's green (open) spaces through item representation (statistically) to set an example in our culture room and found places on Tartu map. For example, it is hard to evaluate the result while there are no evaluations to green areas first. We know the connection between the Man and environment, we know the Man generally well. On environmental side however dendrology and history are not saying much about on the subject, what we can do there and what actions our surroundings are supporting. Concept is to finding it out. In different cultures the results are different. While thinking a bit further, it's a background for hospital areas, where garden therapy is used. If we know the culture background fully, then we can offer the similar environment for recovery for example in Estonia, because here the treatment is cheaper than in Denmark. Aim is to assess the PRS of Tartu City Parks and UGS in order to answer to following questions:

1. To find statistically high quality correlation descriptions about Tartu city parks with example of parks and find the areas in CAD MAP.

2. To find few example high score restoration features in Tartu and descriptions through evaluation items.

\section{Methods}

\section{Questionnaire}

The version of PRS used in this study is based on the version by Hartig et al. (1997a, b), which has 26 items that fall into four subscales: five items are assessed in subscale Being away (e.g. 'It is a place to get away from it all', 'Spending time here gives me a break from my day-to-day routine'); eight items in Fascination (e.g. 'This place has fascinating qualities', My attention is drawn to many interesting things'); four items in Extent (e.g. 'There is a great deal of distraction,' 'It is chaotic here'); nine items in Compatibility (e.g. 'Being here suits my personality', 'I can do things I like here'). In this paper has been measured the four characteristics, i.e. judgement is made in green area on a four-point scale, where 0 means 'no, doesn't exist'; 1 'weak existence', 2 'medium existence', 3 'strong existence' from UGS (See Table 1). One parameter evaluation scale (0-3) is divided equally large. Evaluation took place by using park as evaluation scale. All parks and UGS (incl. what is in and out of city border) were chosen to current research.

\section{Map creation}

Firstly the CAD map was created by borders and codes, after evaluation CAD map was created through topic named layers. The assessment scale was transformed into three positive answer colours: Light tone of colour -
Table 1 PRS questionnaire on a four-point scale

\begin{tabular}{|c|c|c|}
\hline Factor & Item & $\begin{array}{llll}0 & 1 & 2 & 3 \\
\end{array}$ \\
\hline \multirow[t]{5}{*}{ Being away } & 1. Being here is an escape experience & \\
\hline & $\begin{array}{l}\text { 2. Spending time here gives me a break } \\
\text { from my day-to-day routine }\end{array}$ & \\
\hline & 3. It is a place to get away from it all & \\
\hline & $\begin{array}{l}\text { 4. Being here helps me to relax my focus on } \\
\text { getting things done }\end{array}$ & \\
\hline & $\begin{array}{l}\text { 5. Coming here helps me to get relief from } \\
\text { unwanted demands on my attention }\end{array}$ & \\
\hline \multirow[t]{8}{*}{ Fascination } & 6. This place has fascinating qualities & \\
\hline & $\begin{array}{l}\text { 7. My attention is drawn to many interesting } \\
\text { things }\end{array}$ & \\
\hline & 8. I want to get to know this place better & \\
\hline & 9. There is much to explore and discover here & \\
\hline & $\begin{array}{l}\text { 10. I want to spend more time looking at } \\
\text { the surroundings }\end{array}$ & \\
\hline & 11. This place is boring & \\
\hline & 12. The setting is fascinating & \\
\hline & 13. There is nothing worth looking at here & \\
\hline \multirow[t]{4}{*}{ Extent } & 14. There is too much going on & \\
\hline & 15. It is a confusing place & \\
\hline & 16. There is a great deal of distraction & \\
\hline & 17. It is a chaotic place & \\
\hline \multirow[t]{9}{*}{ Compatibility } & 18. Being here suits my personality & \\
\hline & 19. I can do things I like here & \\
\hline & 20. I have a sense that I belong here & \\
\hline & 21. I can find ways to enjoy myself here & \\
\hline & 22. I have a sense of oneness with this setting & \\
\hline & 23. There are landmarks to help me get around & \\
\hline & $\begin{array}{l}\text { 24. I could easily form a mental map of this } \\
\text { place }\end{array}$ & \\
\hline & 25. It is easy to find my way around here & \\
\hline & 26. It is easy to see how things are organized & \\
\hline
\end{tabular}

low presence; Middle tone of colour - medium presence; Dark tone of colour - strong presence. The greenery codes on the map are marked in capital letters, for example A, AV, CD. Same codes are used in tables. Map is made according to the correlations i.e 2 questions, where one has the score (value) of $0-1$ and other has the score (value) of $0-1$, then the result is low. For example: area AA, N... (the ones marked as Low on the map), such as area $B G$, where all the questions received the mark (rating) 0 or 1 . However, if the score (value) of one question is 2 and score (value) of second question is 2 or 3 , then the outcome is average (intermediate/ medium result). For instance the ones that are marked on the map as Middle. Area BS, where all results 
are positive (Being Away, Fascination, Compatibility), has received the mark 2 or 3 . Finally, if first question received the mark 3 and second question received mark 3 as well, then we have high result. For example: areas CL, CO.. (the ones marked as High on the map), that have received mark 3 on all (Being Away, Fascination and Compatibility) questions. In case of Extent the result is negative, therefore, to receive grade $\mathrm{HIGH}$ (HIGH score), score has to be 0 . In other words, the lack of negative score (position). For better orientation the groups in map are created by groups.

\section{Evaluation procedure}

Parks and UGS are found able in Tartu as being connected to river Emajõgi or perimeter of town where main roads go out. While working in "green area/park scale" the results shows overall and "direction" result what you can find there. Assessor was instructed both orally and through written material with notes. Assessments were digitalised in Excel and in an Auto-CAD map. Assessment was carried out in Tartu on June 19, 20 and 27, 2013 by expert/author. Data was collected in similar weather conditions, it was sunny and the air temperature relatively warm. The author has been connected with most of the green areas for three years already; each green area was assessed at least 15 minutes, however more time was allocated on the bigger and less well-known areas (e.g. code AB). The assessments were done according to the questionnaire with 26 items on the earlier prepared questionnaire on paper per park (see Table 1). The evaluation was based on the overall impression of the whole park/UGS.

\section{Statistical data processing}

In order to process the data, data was fed from the paper to MS Excel, and then entered to SPSS 2.0. Information about the green areas was coded in the same way as on the digital map (e.g. A, AV, CD). Under column codes follow the assessing scale (0-3) to questions answered as following: 1 - yes, 0 - no. Descriptive table analyses, e.g. ratio analysis and Pearson linear correlation were used. Significant correlations in this paper start from 0.500 values, variance analysis are not too detailed. The results in this paper are based on the correlations found in statistical data processing, thus significant correlations have $95 \%$ credibility $(\mathrm{p}<0.05)$. For description as one "culture room" uniqueness is coming out by one item question to question correlation result, there is no interpretation needed, for example Item of fascination 'My attention is drawn to many interesting things' correlate with item of Being away 'Being here is like an escape' ( $r=0.689$, $\mathrm{p}<0.05$ ) what is in very detailed level described the situation in greenery and are found able in map BS, AÜ, AK, CL, CP, $\mathrm{CO}, \mathrm{O}, \mathrm{CN}, \mathrm{AR}, \mathrm{BO}$, (See Figure 1/Group III).

\section{Results}

To find statistically high quality correlation descriptions about Tartu city parks with example of parks and in areas in CAD MAP

\section{Fascination + Being away}

Items 'This place has fascinating qualities' and 'Being here is like an escape correlate $(\mathrm{r}=0.760, \mathrm{p}<0.05)$ (see Table 2) in areas BS, AM, AK, CO, CL, CP, CN, O, BJ, $\mathrm{AR}, \mathrm{AE}, \mathrm{BO}$ (See Figure 1). Items 'This place has fascinating qualities' and item 'This place makes it possible for me to rest from daily routine' correlate $(\mathrm{r}=0.847, \mathrm{p}<$ $0.05)$. 'This place has fascinating qualities' correlates with 'It is the place to get away from it all' $(\mathrm{r}=0.864, \mathrm{p}<0.05)$ and with being here helps me to focus on getting things done' $(\mathrm{r}=0.844, \mathrm{p}<0.05)$. Examples with codes: BS, AM, AK, CO, CL, CP, CN, O, BJ, AR, AE, AC, BÕ (See Figure 1. Group II). Item of fascination 'My attention is drawn to many interesting things' correlate with item of Being away 'Being here is like an escape' $(r=0.689, \mathrm{p}<0.05)$ and 'This place makes it possible for me to rest from daily routine' $(r=0.771, \quad p<0.05)$. Both correlations were highly esteemed in areas BS, AÜ, AK, CL, CP, CO, O, $\mathrm{CN}, \mathrm{AR}, \mathrm{BO}$, (See Figure 1/Group III). Items 'My attention is drawn to many interesting things' and 'It is the place to get away from it all' correlate $(\mathrm{r}=$ $0.780, \mathrm{p}<0.05)$, when talking about coded areas BS, $\mathrm{AK}, \mathrm{CP}, \mathrm{CO}, \mathrm{CL}, \mathrm{CN}, \mathrm{AR}$ and $\mathrm{O}$. The first item here also correlates with 'Being here helps me to focus on getting things done' $(\mathrm{r}=0.777, \mathrm{p}<0.05)$ and area coded $\mathrm{OL}$ is added to the list.

OL stands for the Sanatooriumi Park-forest, where thick undergrowth, different paths and varied relief give the impression of being temporarily away and enable to focus on one's own thoughts. But Riia Street with its heavy traffic and Raja Street that divides the park into two halves tends to distract attention. Item 'I want to get to know this place better' correlates with both 'Being here is like an escape' $(\mathrm{r}=0.700, \mathrm{p}<0.05)$ and 'Spending time here gives me a break from my day-to-day routine' $(\mathrm{r}=0.803, \mathrm{p}<0.05)$. Areas BS, AK, CP, CO, CN, O, AR, $\mathrm{BO}$ and CL achieved high marks with these correlations.

Relief at Kassitoome (CL) (including the concavity) attracts people and makes the place interesting, which encourages people to enter the area and explore what else interesting there is to find. In addition, the first-mentioned item also correlates with the item 'Being here helps me to focus on getting things done' $(\mathrm{r}=0.794, \mathrm{p}<0.05)$, but instead of BÕ, the area mentioned is OL. Park-forest on Sanatooriumi Street offers more opportunities for gathering thoughts. The forest-like park makes one feel away from the urban environment. Different zones in the park-forest (forested area, tracks for running, training area) allow engagement in different activities without disturbing others. 


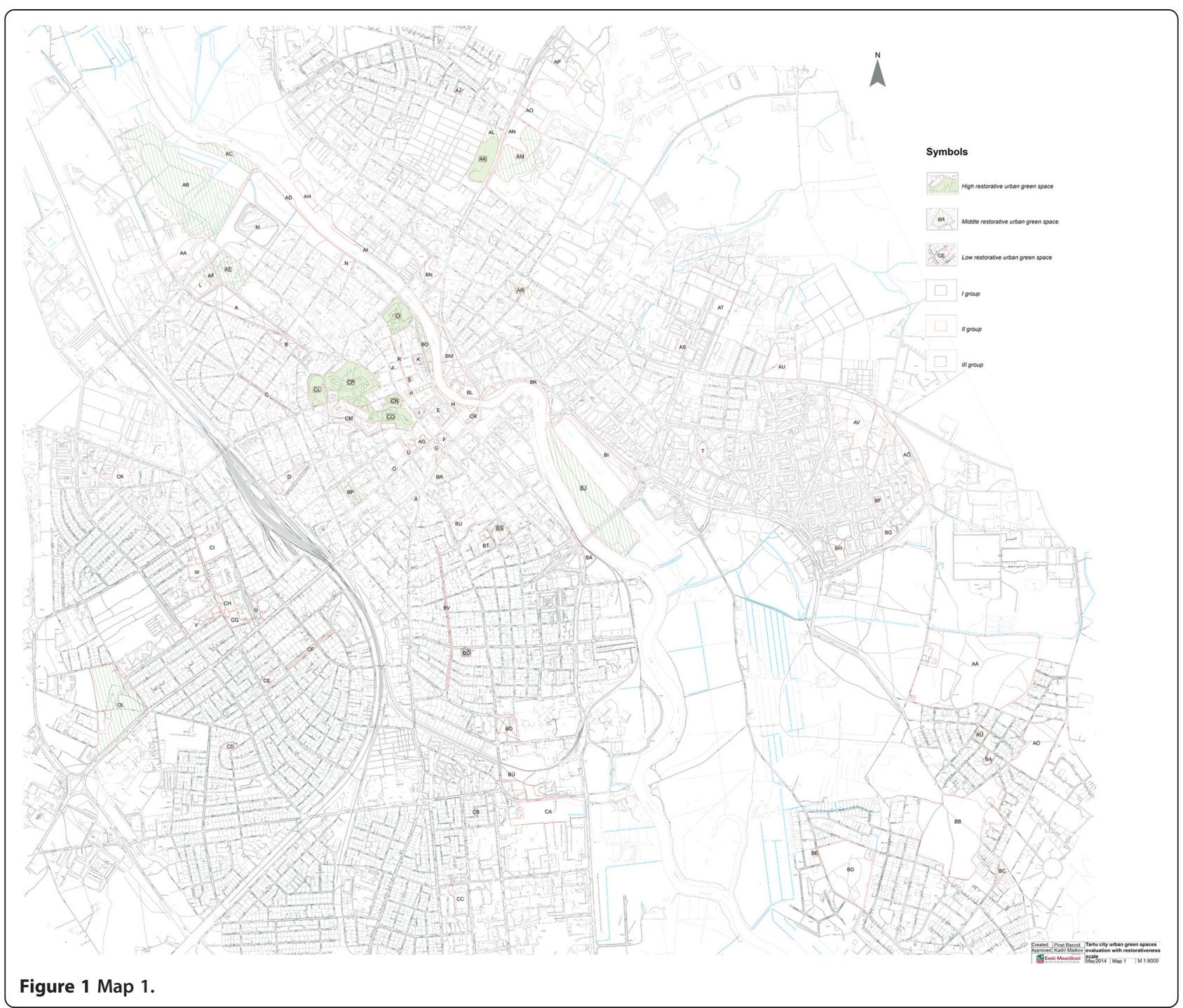

Item 'this place has fascinating qualities' correlates (See Table 3) with 'Being here helps me to focus on getting things done' $(r=0.724, p<0.05)$, 'Coming here helps me to get relief from unwanted demands on my attention' $(\mathrm{r}=0.731, \mathrm{p}<0.05)$ and 'This place has fascinating qualities' ( $r=0.669, \mathrm{p}<0.05)$. BS, AK, CP, CO, CL, CN and $\mathrm{O}$ are areas with strong correlation examples. Let us have a closer look at Karlova Park (BS).

\section{BS - Karlova park}

It is an area covered with deciduous trees, mainly limes (Tilia cordata), which offer shade and coolness in summer. The small amount of shrubbery makes the park airy and the existing lamps inviting. The well-maintained area seems safe and secure. With its several staircases and different levels, the park, raised higher than the streets, arouses immediate interest. The wall, made from quarry stones that at places seem to lay the foundation for the park, draws automatic attention (Fascination). The wall does not seem like a foreign body, but rather helps to form a whole. The park contains items that promote gathering thoughts and escape from unwanted distractions. These are features that confirm the saying 'the more the merrier' does not prove correct every time- nothing too lavish or lacking to block restorativeness. Nothing prevents you from taking along a blanket, spreading it out in the park, switching off your stressful thoughts that may burden your mental health (Extent).

\section{Compatibility and fascination}

Item of compatibility 'I can do things I like here' and item of being away 'Being here is an escape experience' correlate $(\mathrm{r}=0.670, \mathrm{p}<0.05)$ (see Table 4$)$, which comes forward very well in case of the following green areas: $\mathrm{AK}$, $\mathrm{CO}, \mathrm{CL}, \mathrm{CP}, \mathrm{CN}, \mathrm{O}$ and BÕ. Besides that the item of compatibility 'I can do things I like here' also correlates to the 
Table 2 Items under Fascination correlate with items under Being away

\begin{tabular}{|c|c|c|c|c|c|}
\hline & & $\begin{array}{l}\text { Being here is an } \\
\text { escape experience. }\end{array}$ & $\begin{array}{l}\text { Spending time here gives } \\
\text { me a break from my } \\
\text { day-to-day routine. }\end{array}$ & $\begin{array}{l}\text { It is the place to get } \\
\text { away from it all. }\end{array}$ & $\begin{array}{l}\text { Being here helps } \\
\text { me to focus on } \\
\text { getting things done. }\end{array}$ \\
\hline \multirow[t]{3}{*}{$\begin{array}{l}\text { This place has fascinating } \\
\text { qualities. }\end{array}$} & $\begin{array}{l}\text { Pearson } \\
\text { Correlation }\end{array}$ & $.760^{* *}$ & $.847^{* *}$ & $.864^{* *}$ & $.844^{* *}$ \\
\hline & Sig. (2-tailed) & .000 & .000 & .000 & .000 \\
\hline & $\mathrm{N}$ & 92 & 92 & 92 & 92 \\
\hline \multirow[t]{3}{*}{$\begin{array}{l}\text { My attention is drawn to } \\
\text { many interesting things. }\end{array}$} & $\begin{array}{l}\text { Pearson } \\
\text { Correlation }\end{array}$ & $.689^{* *}$ & $.771^{* *}$ & $.780^{* *}$ & $.777^{* *}$ \\
\hline & Sig. (2-tailed) & .000 & .000 & .000 & -000 \\
\hline & $N$ & 92 & 92 & 92 & 92 \\
\hline \multirow[t]{3}{*}{$\begin{array}{l}\text { I want to get to know this } \\
\text { place better. }\end{array}$} & $\begin{array}{l}\text { Pearson } \\
\text { Correlation }\end{array}$ & $.700^{* *}$ & $.803^{* *}$ & $-813^{* *}$ & $-794^{* *}$ \\
\hline & Sig. (2-tailed) & .000 & .000 & -000 & -000 \\
\hline & $N$ & 92 & 92 & 92 & 92 \\
\hline \multirow[t]{3}{*}{$\begin{array}{l}\text { There is much to explore and } \\
\text { discover here. }\end{array}$} & $\begin{array}{l}\text { Pearson } \\
\text { Correlation }\end{array}$ & $.721^{* *}$ & $-751^{* *}$ & $-804^{* *}$ & $.760^{* *}$ \\
\hline & Sig. (2-tailed) & .000 & .000 & .000 & -000 \\
\hline & $N$ & 92 & 92 & 92 & 92 \\
\hline \multirow[t]{3}{*}{$\begin{array}{l}\text { I want to spend more time } \\
\text { looking at the surroundings. }\end{array}$} & $\begin{array}{l}\text { Pearson } \\
\text { Correlation }\end{array}$ & $.747^{* *}$ & $-837^{* *}$ & $-811^{* *}$ & $.831^{* *}$ \\
\hline & Sig. (2-tailed) & .000 & .000 & -000 & .000 \\
\hline & $N$ & 92 & 92 & 92 & 92 \\
\hline
\end{tabular}

${ }^{* *}$ significance $95 \%$.

following items of fascination: 'My attention is drawn to many interesting things' $(\mathrm{r}=0.831, \mathrm{p}<0.05)$; 'I want to get to know this place better' $(\mathrm{r}=0.834, \mathrm{p}<0.05)$; 'There is much to explore and discover here' $(r=0.816, p<0.05)$; 'I want to spend more time looking at the surroundings' $(\mathrm{r}=$ 0.841, $\mathrm{p}<0.05)$; 'This place has fascinating qualities' $(\mathrm{r}=$ $0.744, \mathrm{p}<0.05)$.

In addition, in green areas $\mathrm{CO}, \mathrm{CL}, \mathrm{CP}$ and $\mathrm{O}$ the item of compatibility 'I have a sense that I belong here' correlates with the following items of fascination: 'My attention is drawn to many interesting things' $(\mathrm{r}=0.775, \mathrm{p}<0.05)$; 'I want to get to know this place better' $(\mathrm{r}=0.740, \mathrm{p}<0.05)$; 'There is much to explore and discover here' $(r=0.767$, $\mathrm{p}<0.05$ ); 'I want to spend more time looking at the surroundings' $(r=0.829, p<0.05)$; 'This place has fascinating qualities' $(r=0.780, p<0$.). In areas $\mathrm{CO}, \mathrm{CP}$,
$\mathrm{CL}, \mathrm{AE}, \mathrm{O}$ and $\mathrm{AC}$ item 'I have a sense of oneness with this setting' correlates with 'Spending time here gives me a break from my day-to-day routine' $(\mathrm{r}=0.701, \mathrm{p}<0.05)$; 'It is the place to get away from it all' $(\mathrm{r}=0.754, \mathrm{p}<0.05)$; 'Coming here helps me to get relief from unwanted demands on my attention' $(r=0.732, p<0.05)$ and 'This place has fascinating qualities' $(r=0.752, p<0.05)$.

\section{J - Tõnisson Square}

It is a tiny square at the corner of Ülikooli and Gildi Streets. Some trees grow there. The square is equipped with some benches and lighting and there stands a monument of Jaan Tõnisson. This area of about $300 \mathrm{~m}^{2}$ draws attention (fascination) because it is so different from the surroundings. This is a part of the Old Town

Table 3 Item Fascination correlates with item Being away

\begin{tabular}{|c|c|c|c|c|c|c|}
\hline & & $\begin{array}{l}\text { Being here is } \\
\text { an escape } \\
\text { experience. }\end{array}$ & $\begin{array}{l}\text { Spending time here } \\
\text { gives me a break from } \\
\text { my day-to-day routine. }\end{array}$ & $\begin{array}{l}\text { It is the place to } \\
\text { get away from it all. }\end{array}$ & $\begin{array}{l}\text { Being here helps } \\
\text { me to focus on } \\
\text { getting things done. }\end{array}$ & $\begin{array}{l}\text { Coming here helps } \\
\text { me to get relief from } \\
\text { unwanted demands } \\
\text { on my attention. }\end{array}$ \\
\hline \multirow[t]{3}{*}{$\begin{array}{l}\text { This place has } \\
\text { fascinating qualities. }\end{array}$} & $\begin{array}{l}\text { Pearson } \\
\text { Correlation }\end{array}$ & $.636^{* *}$ & $.672^{* *}$ & $.724^{* *}$ & $.731^{* *}$ & $.669^{* *}$ \\
\hline & Sig. (2-tailed) & -000 & -000 & -000 & -000 & -000 \\
\hline & $\mathrm{N}$ & 92 & 92 & 92 & 92 & 92 \\
\hline
\end{tabular}

**significance $95 \%$. 
Table 4 Items of compatibility correlate with the items of being away and fascination

\begin{tabular}{|c|c|c|c|c|c|c|c|c|c|c|c|c|}
\hline & & $\begin{array}{l}\text { Being here } \\
\text { is an escape } \\
\text { experience. }\end{array}$ & $\begin{array}{l}\text { Spending time } \\
\text { here gives me } \\
\text { a break from } \\
\text { my day-to-day } \\
\text { routine. }\end{array}$ & $\begin{array}{l}\text { It is the } \\
\text { place to } \\
\text { get away } \\
\text { from it all. }\end{array}$ & $\begin{array}{l}\text { Being here } \\
\text { helps me to } \\
\text { focus on } \\
\text { getting } \\
\text { things done. }\end{array}$ & $\begin{array}{l}\text { Coming here helps } \\
\text { me to get relief } \\
\text { from unwanted } \\
\text { demands on my } \\
\text { attention. }\end{array}$ & $\begin{array}{l}\text { This place has } \\
\text { fascinating } \\
\text { qualities. }\end{array}$ & $\begin{array}{l}\text { My attention } \\
\text { is drawn to } \\
\text { many } \\
\text { interesting } \\
\text { things. }\end{array}$ & $\begin{array}{l}\text { I want to } \\
\text { get to know } \\
\text { this place } \\
\text { better. }\end{array}$ & $\begin{array}{l}\text { There is } \\
\text { much to } \\
\text { explore } \\
\text { and } \\
\text { discover } \\
\text { here. }\end{array}$ & $\begin{array}{l}\text { I want to } \\
\text { spend more } \\
\text { time looking } \\
\text { at the } \\
\text { surroundings. }\end{array}$ & $\begin{array}{l}\text { This place } \\
\text { has fascinating } \\
\text { qualities. }\end{array}$ \\
\hline \multirow{3}{*}{$\begin{array}{l}\text { Being here } \\
\text { suits my } \\
\text { personality. }\end{array}$} & $\begin{array}{l}\text { Pearson } \\
\text { Correlation }\end{array}$ & $.643^{* * *}$ & $.696^{* * *}$ & $.783^{* *}$ & $.753^{* *}$ & $.732^{* *}$ & $.777^{* *}$ & $.792^{* *}$ & $.716^{* *}$ & $-776^{* *}$ & $-805^{* *}$ & $-752^{* *}$ \\
\hline & $\begin{array}{l}\text { Sig. } \\
\text { (2-tailed) }\end{array}$ & -000 & .000 & .000 & .000 & .000 & .000 & .000 & .000 & .000 & .000 & .000 \\
\hline & $N$ & 92 & 92 & 92 & 92 & 92 & 92 & 92 & 92 & 92 & 92 & 92 \\
\hline \multirow{3}{*}{$\begin{array}{l}\text { I can do } \\
\text { things } \\
\text { I like here. }\end{array}$} & $\begin{array}{l}\text { Pearson } \\
\text { Correlation }\end{array}$ & $.670^{* *}$ & $.763^{* *}$ & $.739^{* *}$ & $.718^{* *}$ & $.719^{* *}$ & $.770^{* *}$ & $.831^{* *}$ & $.834^{* *}$ & $.816^{* *}$ & $.744^{* *}$ & $.841^{* *}$ \\
\hline & $\begin{array}{l}\text { Sig. } \\
\text { (2-tailed) }\end{array}$ & -000 & .000 & .000 & .000 & .000 & .000 & .000 & .000 & .000 & .000 & .000 \\
\hline & $\mathrm{N}$ & 92 & 92 & 92 & 92 & 92 & 92 & 92 & 92 & 92 & 92 & 92 \\
\hline \multirow{3}{*}{$\begin{array}{l}\text { I have a } \\
\text { sense that } \\
\text { I belong here. }\end{array}$} & $\begin{array}{l}\text { Pearson } \\
\text { Correlation }\end{array}$ & $.633^{* *}$ & $.701^{* *}$ & $.762^{* *}$ & $.743^{* *}$ & $.741^{* *}$ & $.765^{* *}$ & $.775^{* *}$ & $.740^{* *}$ & $.767^{* *}$ & $.829^{* *}$ & $-.780^{* *}$ \\
\hline & $\begin{array}{l}\text { Sig. } \\
\text { (2-tailed) }\end{array}$ & -000 & .000 & .000 & .000 & .000 & .000 & .000 & .000 & .000 & .000 & .000 \\
\hline & $\mathrm{N}$ & 92 & 92 & 92 & 92 & 92 & 92 & 92 & 92 & 92 & 92 & 92 \\
\hline \multirow{3}{*}{$\begin{array}{l}\text { I can find } \\
\text { ways to enjoy } \\
\text { myself here. }\end{array}$} & $\begin{array}{l}\text { Pearson } \\
\text { Correlation }\end{array}$ & $.620^{* *}$ & $.704^{* *}$ & $.731^{* *}$ & $.693^{* *}$ & $.708^{* *}$ & $.748^{* *}$ & $.811^{* *}$ & $.830^{* *}$ & $.782^{* *}$ & $.719^{* *}$ & $.795^{* *}$ \\
\hline & $\begin{array}{l}\text { Sig. } \\
\text { (2-tailed) }\end{array}$ & -000 & .000 & .000 & .000 & .000 & .000 & .000 & .000 & .000 & .000 & .000 \\
\hline & $\mathrm{N}$ & 92 & 92 & 92 & 92 & 92 & 92 & 92 & 92 & 92 & 92 & 92 \\
\hline \multirow{3}{*}{$\begin{array}{l}\text { I have a } \\
\text { sense of } \\
\text { oneness } \\
\text { with this } \\
\text { setting. }\end{array}$} & $\begin{array}{l}\text { Pearson } \\
\text { Correlation }\end{array}$ & $.650^{* *}$ & $.701^{* *}$ & $.754^{* *}$ & $.732^{* *}$ & $.732^{* * *}$ & $.752^{* * *}$ & $.747^{* *}$ & $.713^{* *}$ & $.750^{* *}$ & $.777^{* *}$ & $.762^{* * *}$ \\
\hline & $\begin{array}{l}\text { Sig. } \\
\text { (2-tailed) }\end{array}$ & -000 & .000 & .000 & .000 & .000 & .000 & .000 & .000 & .000 & .000 & .000 \\
\hline & $\mathrm{N}$ & 92 & 92 & 92 & 92 & 92 & 92 & 92 & 92 & 92 & 92 & 92 \\
\hline \multirow{3}{*}{$\begin{array}{l}\text { There are } \\
\text { landmarks to } \\
\text { help me to } \\
\text { get around. }\end{array}$} & $\begin{array}{l}\text { Pearson } \\
\text { Correlation }\end{array}$ & $.381^{* *}$ & $.489^{* *}$ & $.476^{* *}$ & $.451^{* *}$ & $.450^{* *}$ & $.513^{* *}$ & $.628^{* *}$ &, $.20^{* *}$ & $.544^{* *}$ & $.578^{* *}$ & $.584^{* * *}$ \\
\hline & $\begin{array}{l}\text { Sig. } \\
\text { (2-tailed) }\end{array}$ & -000 & .000 & .000 & .000 & .000 & .000 & .000 & .000 & .000 & .000 & .000 \\
\hline & $\mathrm{N}$ & 92 & 92 & 92 & 92 & 92 & 92 & 92 & 92 & 92 & 92 & 92 \\
\hline
\end{tabular}

**significance $95 \%$. 
where the houses stand densely next to each other and streets or courtyards behind high fences form open spaces. Therefore this open space captures people's attention at once. It is not a typical space covered with lawn adds but a multi-level well-lit open area, where different materials have been used. At the same time it is a comfortable place for it is surrounded by different walls (lattice girder, concrete, pillars, etc.) that make people feel safe and, taking into account the small size of the walls, also isolated enough to feel well.

\section{To find few example high score restoration features in} Tartu and describe them through evaluation items

These are UGS-s (see Figure 2), where all or at least three of the ART subscales is strongly represented -high scores in PRS assessments and examples of strong correlations.

\section{CP-Toome Hill (Including CO - the surroundings of the Tartu Observatory)}

The park on Toome Hill consists of areas that are large in size and that are, for the sake of perception and comprehension, earmarked separately on the map so that the negative features of one area would not have an impact on the other areas. The analysis shows that in case of $\mathrm{CP}$ and $\mathrm{CO}$ the assessments are strongly positive and that is why they have been handled as a whole here. Different levels, but first and foremost the natural relief is the main attraction here. High and massive buildings that give an idea about the singularity and grandeur of this place intensify this feeling even more. Variability (playgrounds, monuments, historic and state buildings, bridges, etc.) attaches more value to this place. At the first glance it is difficult to perceive the extent of the area, but when spending more time there one starts to appreciate its coherence and harmony (Extent). Different zones (e.g. a playground at the foot of the hill) make it possible to use the area according to one's preferences and do not make Toome Hill with its history illiberally attractive to the historians only. Therefore this area calls for a longer stay and absorption even if in one's thoughts (Being away), which explains well, why it was necessary to split the area into two.

\section{CL-Kassitoome}

Kassitoome is an emotionally strong UGS (Fascination) in Tartu. It is a space with a varied relief and logically running paths (Extent), which make it possible to view the area from different levels. Airiness (scarce tall trees) and well-groomed park make it easier for the observer to perceive the scope, volume and unity of the area. The well-known Kassitoome Valley (an old sand- and gravel-pit) offers activities all the year round. Besides all that, it is nice to stroll about, feel secluded while sitting in the valley, have a look at the historic buildings surrounding the park and be absorbed in one's thoughts (Being away). The few trees and the shadows they cast, make the valley cozier and more natural, which on the basis of ART feels more genuine to people than urban environment. It is a good example of something artificial being conflated into the urban environment so that it seems natural. It is definitely a place, which has obtained its soul through human action. We might boldly say that it is the favourite place for a lot of people (Compatibility).

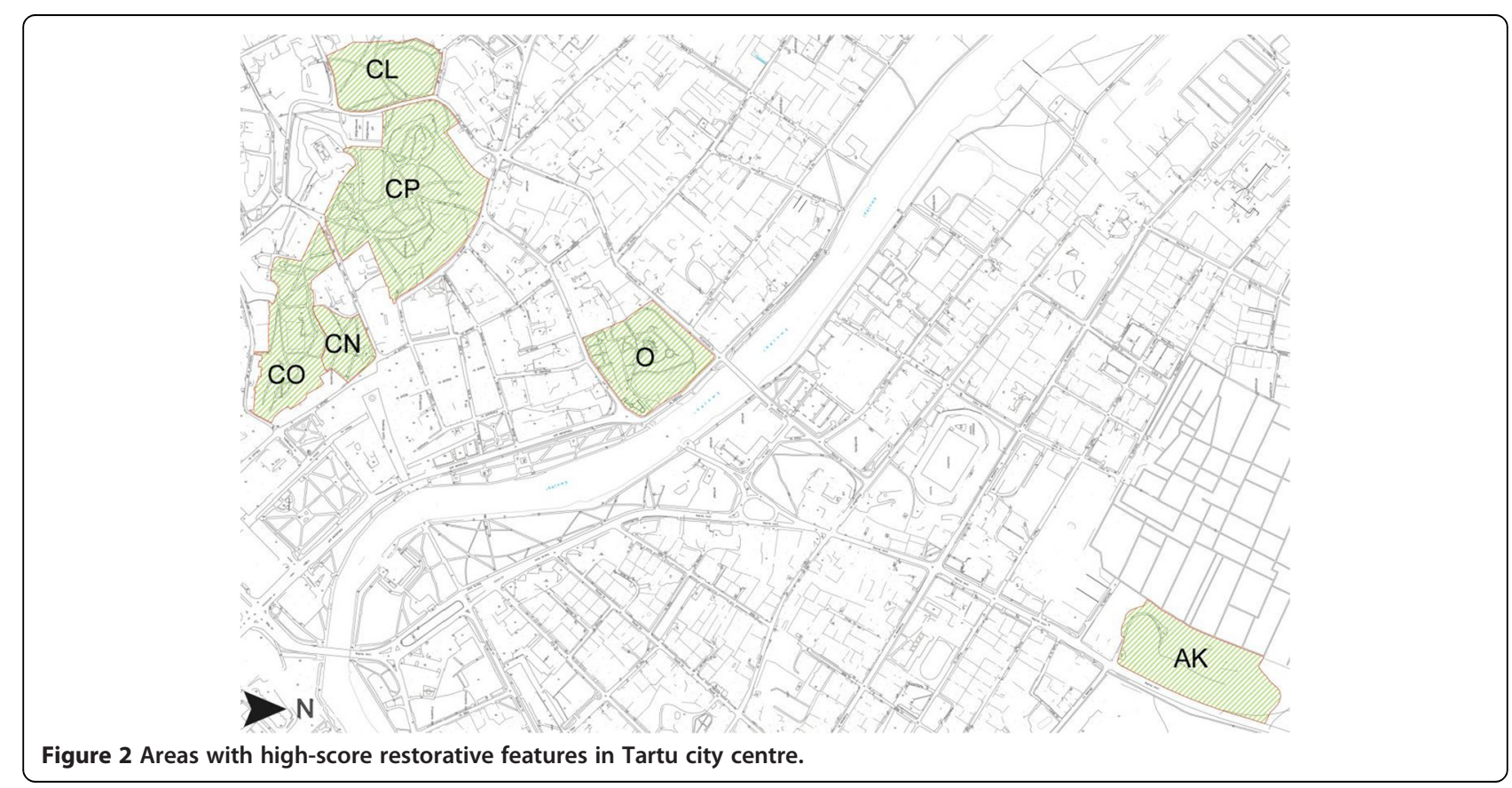




\section{Discussion}

\section{Open green spaces and earlier research}

The results of the present paper comply with the results of earlier studies and articles based on them. Kaplan \& Kaplan 1989; Hartig et al. 1991; Kaplan 1995; Hartig et al. 1997a, b; Laumann et al. 2001; Maikov 2013 claim that restorativeness is higher in the natural environment than in artificial surroundings. However, the artificial environment may include natural components that make it possible for the people to perceive restorativeness in urban surroundings. The PRS analysis in this paper shows that artificial environment with natural components (e.g. Kassitoome valley - CL) may have restorative potential. In addition, natural environment with artificial components (e.g. Tartu Adventure Park - AK) gives a positive result and proves that natural and artificial elements may offer people the opportunity to recover from every-day disturbances. But both elements must be in proportion and in harmony. A setting may have a strong Being away perception, but if it is not attractive enough (i.e. the first impression is not attractive enough) people will not enter the area. In the same way areas $\mathrm{BD}, \mathrm{BB}$ and $\mathrm{AÖ}$ (See Figure 1) that may for some reason be important for the local people (good forest for picking mushrooms; a source of fresh air, etc.), but strangers may not understand that. They might appreciate the fresh air and admire the growing pines (Pinus sylvestris), but not the area as a whole. Van den Berg et al. (2007) said that natural environment offers a more efficient way to recover from mental fatigue and stress than the urban surroundings. On the basis of the present paper we may say that when comparing the UGS in the centre of the town (e.g. O, CP, $\mathrm{CL})$ with the ones on the outskirts $(\mathrm{AB}, \mathrm{BB}, \mathrm{A} \ddot{\mathrm{A}}, \mathrm{AP})$ the PRS analysis shows that urban environment can offer more restorative opportunities in a short time than a forest-like area outside the town. People appreciate the customary open spaces in their every-day environment, which value (including restorativeness) rather increases than decreases over the time. This, in its turn, proves the statement by Nordh et al. (2009) that even the smallest UGS in the neighbourhood may possess significant restorative features, and UGS that are closer to home may be more popular and preferred for restoration just due to their location. The comparison between large and small green areas supports the opinion of Nordh et al. (2009), which states that the size of the UGS does not necessarily affect the power of perceived restorativeness. Restorativeness is more likely influenced by the preference of the people and the existence of different elements. This can be illustrated by the comparison of Tonnisson Square (J) and Politsei Square (K). Several authors (Kaplan \& Kaplan 1989; Kaplan 1995; Hartig et al. 1997a, b; Laumann et al. 2001) have claimed that artificial environment may have a smaller impact on restorativeness than natural environment and the present paper supports this idea. For example, the restorativeness of Tartu Town Hall Square $(\mathrm{P})$ is not as strong as that of Pirogov Park $(\mathrm{CN})$. At the same time the correlation $(\mathrm{r}=0.524, \mathrm{p}<$ 0.05) indicates that Town Hall Square is an attractive place. It is well organized and has landmarks (e.g. rows of lights, pavement stones of different colour, etc.) which facilitate traffic. Unfortunately, the place lacks the something that is necessary for Being away (e.g. large crowds of people, open-air restaurants and artificial materials impose stress) our minds are set on something else. Korpela \& Hartig (1996) have said that strong Compatibility cannot be found in a place which lacks the items of Being away, Fascination and Extent. It means that the items are inter-related.

In all UGS that scored high in Compatibility there are features that are associated with Being away, Fascination and Extent. The examples in Tartu include CP, CO, CL, $\mathrm{CN}, \mathrm{O}$ and AK. Bagot (2004) also confirms that restorativeness is greater if it includes items on all four ART subscales. The PRS analysis on the 92 Tartu UGS shows that in case of 22 green areas the items (e.g. Being away and Fascination) on two subscales (the value of each item is 'three') correlated and the restorativeness of these areas is scored 'average'. These are environments where restorativeness can be felt to a smaller or greater extent (See Figure 1). The codes of these UGS are: BS, AÜ, AM, $\mathrm{AL}, \mathrm{AK}, \mathrm{BE}, \mathrm{BR}, \mathrm{BP}, \mathrm{CO}, \mathrm{CL}, \mathrm{CP}, \mathrm{CN}, \mathrm{P}, \mathrm{S}, \mathrm{BO}, \mathrm{O}, \mathrm{J}, \mathrm{BJ}$, $\mathrm{AR}, \mathrm{OL}, \mathrm{CH}, \mathrm{AB}, \mathrm{AF}, \mathrm{AE}, \mathrm{AC}, \mathrm{BC}, \mathrm{BO}, \mathrm{CB}$. Statistical data supports the hypothesis. In Tartu there are also places that attract people strongly, e.g. $\mathrm{AK}, \mathrm{CO}, \mathrm{CL}, \mathrm{CP}, \mathrm{CN}, \mathrm{O}, \mathrm{AF}$, BÕ, BS, AÜ, BJ, AR, AE, AC, AM, OL, AB (See Figure 1). The analysis confirmed the second hypothesis: Compatibility plays an important role between the perception of landscape and human perception, both within one component as well as between different components. This constituted the bulk of positive results and it is characteristic of several green areas in Tartu. For example, the items of Compatibility (See appendix 1, items 18-23) correlate with all the items of Fascination and Being away. Korpela \& Hartig confirm the strong inter-relation in their study in 1996, where they state that it is impossible to find high Compatibility in settings that lack such items as Being away, Fascination or Extent. The following green areas belong here: $\mathrm{AK}, \mathrm{CO}, \mathrm{CL}, \mathrm{CP}, \mathrm{O}, \mathrm{AE}, \mathrm{BO}, \mathrm{AC}, \mathrm{CN}, \mathrm{J}$, AF, P, BO, OL, AÜ (See Figure 1). The results confirming the third hypothesis Within one town it is possible to find domineering parks/places that illustrate the distinctive character of a specific cultural space show that in Tartu there are at least six areas, that include all or at least three PRS subscales (Being away, Fascination, Extent and Compatibility). These are: Toome Hill together with the surroundings of the Tartu Observatory 
(CP, CO), Kassitoome (CL), Pirogov Park (CN), Botanical Gardens of the University of Tartu (O) and Tartu Adventure Park (AK).

\section{Using the method as evaluation tool for open spaces}

The items chosen for evaluation look subjective, but authors believe that if a different evaluator from the same culture room would do such an evaluation again, the professional opinion would be the same, because the assessing scale 0-3 is very wide. Green spaces are only maintained, which means that they look similar for decades. UGS in Tartu are compact enough to evaluate the parks in 15 minutes. Method is repeatable in any landscapes. Maps also show that square shaped park areas are perfect to find the information about green spaces. Park scale could look too big; no subdivisions in the area, but our characteristics for green areas are the same, that's why we can do it on a big scale.

\section{Competing interests}

The authors declare that they have no competing interests.

\section{Authors' contributions}

KM carried out the healing gardens and environmental psychology studies in landscape architecture, and prepared the current study, and drafted the manuscript. PR have done master work of this study, drafted the manuscript, supervised by KM. Both authors read and approved the final version of the manuscript.

\section{Acknowledgments}

Digital CAD-MAP was received from Tartu City Government through bilateral agreement between them and Estonian University of Life Sciences.

Received: 8 July 2014 Accepted: 11 December 2014

Published online: 26 February 2015

\section{References}

Bagot KL (2004) Perceived Restorative Components: A Scale for Children. Children, Youth and Environments 14(1):107-129

Berto R (2005) Exposure to restorative environments helps restore attentional capacity. J Environ Psychol 25(3):249-259

Berto R, Massacessesi S, Pasini M (2008) Do eye movements measured across high and low fascination photographs differ? Addressing Kaplan's fascination hypothesis. J Environ Psychol 28:185-19

Bodin M, Hartig T (2003) Does the outdoor environment matter for psychological restoration gained through running? Psychology of Sport and Exercise 4(2):141-153

Coley RL, Kuo FE, Sullivan WC (1997) Where does community grow? The social context created by nature in urban public housing. Environ Behav 29:468-492

Gibson JJ (1979) The ecological approach to visual perception. Houghton Mifflin, Boston, p 332

Gillis AR (1974) Population density and social pathology: the case of building type, social allowance and juvenile delinquency. Social forces 53:306-314

Han KT (2003) A Reliable and valid self-rating measure of the restorative quality of natural environments. Landsc Urban Plan 64:209-232

Hartig T, Kaiser FG, Bowler PA (1997a) Further development of a measure of perceived environmental restorativeness. Working paper No. 5, Institute for Housing Research, Uppsala University. Working Paper No. 5

Hartig T, Kaiser FG, Bowler PA (2001) Psychological restoration in nature as a positive motivation for ecological behavior. Environ Behav 33(4):590-607

Hartig T, Korpela K, Evans GW, Gärling T (1996) Validation of a measure of perceived environmental restorativeness, No. 7. Göteborg Psychological Reports, Göteborg Psychological Reports 26.
Hartig T, Korpela K, Evans GW, Gärling T (1997b) A measure of restorative quality in environments. Scandinavian Housing and Planning Research 14(4):175-194

Hartig T, Mang M, Evans GW (1991) Restorative effects of natural environment experiences. Environ Behav 23:3-26

Haurua K, Lehvävirtaa S, Korpela K, Kotzea DJ (2012) Closure of view to the urban matrix has positive effects on perceived restorativeness in urban forests in Helsinki, Finland. Landsc Urban Plan 107:361-369

Herzog TR, Maguire CP, Nebel MB (2003) Assessing the restorative components of environments. J Environ Psychol 23:159-170

Ivarsson CT, Hagerhall CM (2008) The Perceived Restorativeness Of Gardens Assessing The Restorativeness Of A Mixed Built And Natural Scene Type. Urban For Urban Green 7:107-118

Kaplan R, Kaplan S (1989) The experience of nature: A psychological perspective. Cambridge University Press, Cambridge

Kaplan S (1995) The restorative benefits of nature: oward an integrative framework. J Environ Psychol 15:169-182

Korpela K, Hartig T (1996) Restorative qualities of favorite places. J Environ Psychol 16(3):221-233

Kaplan R (2001) The nature of the view from home: Psychological benefits. Environ Behav 33:507-542

Korpela K, Hartig T, Kaiser FG, Fuhrer U (2001) Restorative experience and self-regulation in favorite places. Environ Behav 33(4):572-589

Laumann K, Gärling T, Stormark KM (2001) Rating scale measures of restorative components of environments. J Environ Psychol 21(1):31-44

Maikov K (2013) Landscape characteristics in Tartu City parks - user influences through Design. Wessex Institute of Technology Press, Sustainable city, 353-364

Nordh H, Hartig T, Hagerhall CM, Fry G (2009) Components of small urban parks that predict the possibility for restoration. Urban For Urban Green 8(4):225-235

Pasini M, Berto R, Scopelliti M, Carrus G (2009) Measuring the restorative value of the environment: Contribution to the validation of the Italian version of the Perceived Restorativeness Scale. Bollettino di psicologia applicata 257:3-11

Rosenblad Y (2002) Estonian landscapes as places for mental restoration. masterwork, Tallinn University

Tenngart IC, Hagerhall CM (2008) The perceived restorativeness of gardens - Assessing the restorativeness of a mixed built and natural scene type. Urban For Urban Green 7(2):107-118

Stigsdotter U, Grahn P (2002) What Makes a Garden a Healing Garden? Journal of Therapeutic Horticulture vol 13:60-69

Stigsdotter UK, Grahn P (2011) Stressed individuals' preferences for activities and environmental characteristics in green spaces. Urban For Urban Green 10(4):295-304

Tian L (2012) Waiting Areas of Airports as Restorative Environments for Travelers. A thesis submitted in fulfillment of the requirements for the degree of Mphil of Risk psychology, Environment and Safety at Norwegian University of Science and Technology

Van den Berg AE, Hartig T, Staats H (2007) Preference for Nature in Urbanized Societies: Stress, Restoration, and the Pursuit of Sustainability. J Soc Issues 63(1):79-96

Wilson EO (1993) Biophilia and the Conservation Ethic. In: Kellert S, Wilson EO (eds) The Biophilia Hypothesis. Shearwater Books, Washington, D.C, pp 31-40

\section{Submit your manuscript to a SpringerOpen ${ }^{\circ}$ journal and benefit from:}

- Convenient online submission

- Rigorous peer review

- Immediate publication on acceptance

- Open access: articles freely available online

- High visibility within the field

- Retaining the copyright to your article

Submit your next manuscript at $\gg$ springeropen.com 